\title{
CORPORATE SOCIAL RESPONSIBILITY OF SMES IN THE REPUBLIC OF CROATIA
}

\begin{abstract}
From a long-term perspective, modern capitalism does not only require companies to profit as much as possible, but is increasingly paying attention to the social and environmental problems of business. It refers to meeting the social and environmental needs of the wider community. Climate change affecting the extinction of biological species has a major impact on human life and the global economic crisis, which increasingly requires corporations to care about global environmental impact and bio-sustainability, which requires strengthening corporate responsibility with increasing attention to social and environmental problem. The main objective of this paper is to examine the representation of the CSR strategy in small and medium-sized enterprises in the Republic of Croatia, looking through the economic, social and environmental dimensions. An analysis of the application of the existing level of socially responsible business was made, as well as a comparison of the levels of implementation of the social and environmental dimension in the observed SMES. The empirical research in this paper concludes that the sample SMEs are oriented towards the operational and financial aspects of business, while at the same time adopting business strategies across all three dimensions of CSR.
\end{abstract}

Keywords: Corporate Social Responsibility, SMEs

JEL: L26, Q56, G32

\section{INTRODUCTION}

The global economy and the world economy have been constantly changing over the last decades, as the balance between business and civil society is being questioned. Particular attention is paid to social responsibility as a strategic mission and business practice of the company. More recently, companies, especially large corporations, have shown a willingness to demonstrate socially responsible behavior. Corporate Social Responsibility Strategies is a concept in which companies integrate environmental and social concerns into their operations, as well as in relation to all stake-

1 univ.spec.oec., Veleučilište „Nikola Tesla“ u Gospiću 
holders and the community. Corporate social responsibility still implies voluntary business practices, which significantly affect the views of the stakeholders in which the company operates. Being socially responsible involves not only fulfillment of legal obligations but the sustainable investment of capital. In addition to making a profit, modern business practice requires a holistic business approach, that is striking a balance between the economic, social and environmental dimensions of corporate responsibility. This paper seeks to investigate whether and to what extent small and medium sized enterprises in the Republic of Croatia apply the CSR strategy. SMEs in the short term are focused on corporate social responsibility, which also implies that they are focused on the economically operational and financial aspect of the business, while less attention is paid to environmental and social aspects. The empirical research in this paper sought to find out whether and to what extent small and medium sized enterprises in the Republic of Croatia apply the CSR strategy and how much the implementation of the CSR strategy contributes to improving business efficiency.

\section{CSR in small and medium-sized enterprises}

It is clear that the corporate social responsibility of large corporations has been talked about for a long time, however, as SMEs have become the bearers of economic progress, small and medium-sized enterprises have started to talk about corporate social responsibility. Corporate Social Responsibility understands the principles and determines the ways in which businesses should act in accordance with the constant social changes in norms and rules. The concept of CSR is based on the relationship between the business world and the social environment in which the enterprise operates. Rapid industrialization and globalization have led to an alarming situation in terms of lack of awareness and concern for the local community and especially for the environment. CSR involves voluntary activities that go beyond the level of mandatory legal norms that companies are legally required to implement (Vinšalek Stipić, 2017). Corporate Social Responsibility is an ethical and socially responsible attitude towards groups of interest within and outside the company. The aim of social responsibility is to at the same time, while maintaining profitability, create high standards of living for those of interest (Hopkins, 2006). CSR in SMEs can be seen as a business strategy that is integrated as a core business objective in order to improve the competencies of the enterprise in order to create added business value and positive social change (Leadbeater, 1997). The old concept of operating a business was entirely based on generating profits, but in recent times, companies are aware that their success is measured not only in terms of positive financial performance but in creating a positive corporate brand and identity. Management and business owners consider it vital to preserve the value of the company, that is intangible assets such as 
brand strength and corporate image and customer loyalty (McWilliams and Siegel, 2000). There are several motives among scientists, practitioners and politicians that SMEs do not have a major impact on the global economy, which means that no particular attention should be paid to the socially responsible business of SMEs. SMEs can easily and seamlessly adopt the techniques and strategies of large corporations as they choose to engage in CSR activities (Tilley, 2000). This claim cannot be disagreed given that we have been witnessing for a number of years that SMEs are the drivers of economic activity and therefore special attention should be paid to their socially responsible business.

\section{The importance of SMEs for CSR development}

The importance of small and medium-sized enterprises for the development of corporate social responsibility at the global level must not be overstated or neglected when conducting research. It is not uncommon to hear comments from managers or the scientific profession that it is not important to know the development and application of SMEs because, in order to understand contemporary global economic trends, the involvement of multinational companies in corporate social responsibility should be studied because their actions are important. However, we cannot agree that the importance of applying CSR to multinational companies has a much greater impact on the global economy than SMEs. According to a 2001 report from the European Commission, SMEs have a significant impact on the European economy and talk about large-scale SMEs and their contribution to social and economic coherence in the European economy:

- Ninety-nine percent of all businesses in Europe are SMEs

- SMEs are dominant in the contribution of GDP

- SMEs have more labor-intensive production processes than large enterprises

- SMEs have a major impact on the labor market

- SMEs provide around 76 million jobs in the EU

- countries with high SMEs have relatively equal income distributions and promote social stability

- SMEs are a significant resource for innovation in niche markets that require high utilization and sustainable production

- SMEs are the basis for the long-term dynamics of growth and development of large economies 
Beyond the usual benefits of the CSR concept shared by SMEs versus large corporations, it is necessary to highlight the difference in the goals and results of CSR implementation. Particular emphasis is placed on the reliability and dependence of SMEs on interpersonal relationships with different stakeholders, including competition (Spence et al., 2003). In this context, cross-sectoral networking, volunteerism and charitable giving provide an exceptional opportunity to invest in social capital, as well as foster close relationships in the social and business environment. In this way SMEs can establish mutual assistance relationships functional for stability and survival in a competitive market environment. Adopting the CSR concept SMEs can enhance reputation and foster trust, loyalty and stability in terms of a reliable workforce, the confidence of financial institutions, suppliers and business partners. Implementing CSR is not an easy task for SMEs but it also presents a number of challenges. The involvement of small and medium-sized enterprises in global supply chains poses a dilemma as large multinational companies are considered to regulate the behavior of small and medium-sized enterprises against their interests. On the other hand SMEs, have extensive innovation experience in a market environment, and must focus on developing business opportunities using CSR. SMEs have created innovation as a result of the application of CSR principles (Maloni and Brown, 2006). SMEs perceive CSR as a business opportunity to create a new platform for competitiveness, although it is thought that CSR represents a new burden and threat. Many SMEs fear that they will not be able to meet the social and environmental demands of customers and supply chains without losing competitive advantage in the national and global markets. Furthermore, many small and medium-sized enterprises are encouraged to integrate social responsibility business because of the personal beliefs and moral values of the founders, who are often owners and managers, as well as employees (Vallentin and Morsing, 2008). The implementation of the CSR strategy is most often an incentive for SMEs to improve social initiatives. However, the immediate benefits of implementing a CSR policy may even surprise small and medium-sized enterprises, such as financial savings, reducing water and electricity consumption, as well as improving the environment, such as the separation of useful waste for recycling, thereby automatically saving municipal waste costs. Then social improvements, eg reducing risks for workers by improving working and health conditions, which benefit both employees and businesses and equally important product improvements through sustainable production, resulting in better product quality, higher yields and reduced production waste.

\section{CSR of small and medium enterprises in the Republic of Croatia}

Corporate Social Responsibility entails the basis of sustainable business, sustainable management of natural resources and care for society as a whole. As has been said 
many times before, the concept of CSR implies sustainable development through an economic, social and environmental dimension, including notions of economic well-being, environmental protection and social justice, with sustainability as the principle and benchmark of business strategy. While CSR is primarily focused on entrepreneurship and business, sustainable development is conditioned by the continued prosperity of all life forms on earth. Ultimately, we can say that CSR is linked to sustainability, interest groups and ethical business (World Bank, 2005). CSR in Croatia has found its way through its sister companies, or subsidiaries of large multinational companies. Increasing awareness of corporate social responsibility among Croatian companies begins with the European process of integration and accession to the European Union. More active implementation of CSR strategy and upgrading to the business politicl of Croatian companies becomes more intensive with the adoption of legal regulations for CSR implementation measures. With the adoption of the Sustainable Development Strategy of the Republic of Croatia, the legislation expects the implementation of sustainable development standards, although CSR is not considered as a legally binding provision in Croatia and is voluntary for small and medium-sized enterprises. However, through the implementation of CSR rules, Croatia aligns its norms with those of the European Union. CSR reporting in Croatia, as in most EU countries, is on a voluntary basis where the contents of the report are defined on a voluntary basis. Accordingly, small and medium-sized enterprises in Croatia see the application of the CSR concept as additional operating expenditures until they see sufficient cost benefits. The goals of CSR implementation and reporting on the so-called non-financial reporting (CSR Report) has shown benefits for private and public companies, in particular for analyzing and improving sustainable business. Reporting provides information to the wider community about responsible business operations, resulting in loyalty and trust from customers, financial institutions, suppliers and business partners, which is of particular importance for the survival of small and medium-sized enterprises in the global market.

\section{Research goals and hypotheses}

Focusing on profitability with CSR are the end points of the business economy. Rapid technological advancements are making the business models used by SMEs insufficient to manage in a competitive environment. The implementation of CSR strategies and reporting on them leads to building trust between the company and its business partners, where great emphasis is placed on employees and customers, as a confirmation of a positive attitude towards the wider community. The subject of the research involves identifying the financial efficiency factors that are associated with the application of the CSR strategy, its integrated action through corporate governance to profit. 
This empirical study seeks to understand the extent to which small and medium-sized enterprises in the Republic of Croatia are oriented towards the implementation of a corporate social responsibility strategy and they are more oriented to profit than socially responsible for their activities to the wider community and to explore the positive impact of developing operational and strategic plans applying the CSR concept to profitability. In accordance with the above, the following hypotheses of the research were set:

$H 1=$ There is a statistical significance of the correlation between the degree of implementation of CSR strategy and the efficiency of small and medium-sized enterprises

$H 2=$ The SMEs of the Republic of Croatia attach great importance to the implementation of the CSR strategy

\section{Research methodology}

A systematic approach to the problem was required to conduct this empirical research because of the need to determine the application of the CSR strategy from a profitable point of view as a starting point. The analysis of the situation, current state of application of the CSR convention, was carried out on a sample of 127 small and medium-sized enterprises registered and operating in the Republic of Croatia. The data were collected through a survey method, by telephone or e-mail, in the period 1 November 2019 to 15 December 2019. In their processing logical and analytical procedures were used and based on the findings conclusions were reached at the level of the average business entity, which by applying the CSR concept realized profitability. The survey questionnaire is structured from general questions that cover knowledge of the concept of CSR, as well as specific questions about attitudes, implementation and application of CSR. However, in order to exclude the time lag between the reporting period and the time of poll completion, the accepted surveys are valid as those surveys in which it was answered that the degree of application of the CSR concept has not changed since the reporting period as on 31 December 2018. For the independent variable, the level of CSR application was answered (low $=1$, medium $=2$ and high $=3$ points) to obtain information on the appropriate level of CSR implementation of the analyzed SMEs in the Republic of Croatia. The dependent variables are derived from the calculation from the financial statements of the analyzed companies as at 31 December 2018 access to the Croatian Chamber of Commerce's database available at https://digitalnakomora.hr while SPSS Statistics 17.0 was used to process the collected data. 
The following variables are defined in this study:

a) Variable $\mathrm{X}$ - Degree of conceptualization of $\mathrm{CSR}=>$ this characteristic was determined from the questionnaire as:

1. High level of application of CSR concept (3 points)

2. Intermediate level of CSR concept application (2 points)

3. Low level of implementation of CSR concept (1 point)

b) Variables $Y$ of operating efficiency obtained from the calculation from the financial statements of the analyzed companies as at 31 December 2018:

- VAR Y1 - Raturn On Sales (ROS)

- VAR Y2 - Return On Assets (ROA)

- VAR Y3 - Return On Equity (ROE)

This research has raised the need to understand the application of the concept of CSR in small and medium-sized enterprises of the Republic of Croatia as a precondition for profitability.

\subsection{Research results}

The results of the survey are presented below and 127 valid survey questionnaires were returned for data analysis, which all the questions were answered. In a total sample of 127 companies, $59.84 \%$ of managers and/or business owners filled in the survey, while other surveys $41.16 \%$ were filled by employees without managerial functions in the company for which they provided answers. The observed enterprises from the sample according to the number of employees are classified into three groups: the first group, 57 of them, consist of enterprises with 1 to 10 employees, then 43 enterprises with 11 to 50 employees and enterprises with more than 51 employees make them 27.

Chart 1: Enterprises by number of employee

Chart 2. Enterprises by activity
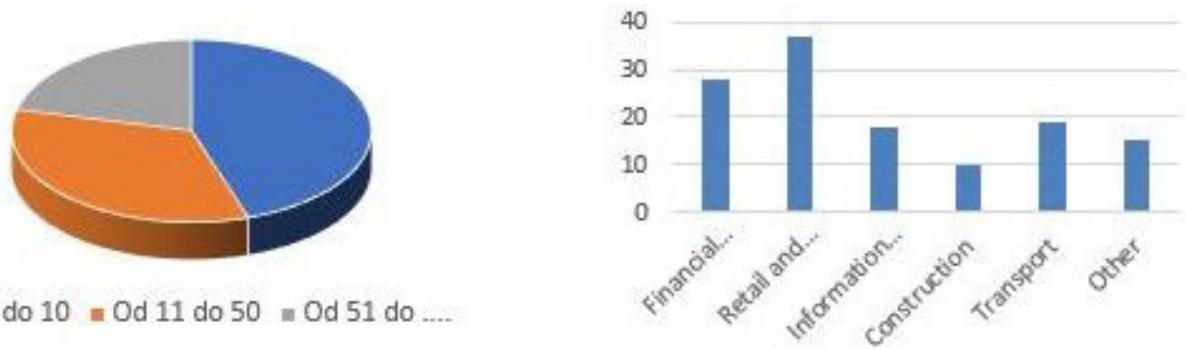

Source: author own study

Source: author own study 
In the observed sample of the analyzed companies from the point of view of the activity they are engaged in, most of them belong to the retail and wholesale trade, followed by the enterprises whose main activity is financial operations (bookkeeping and financial consulting), then the enterprises whose main activity is transport, then information technology and communications, the last places are construction and other activities, as shown in Chart 2.

Chart 3. Corporate attitude to CSR provisions (1-absolutely disagree, 2-disagree, 3- neither agree nor disagree, 4-agree, 5-strongly agree)

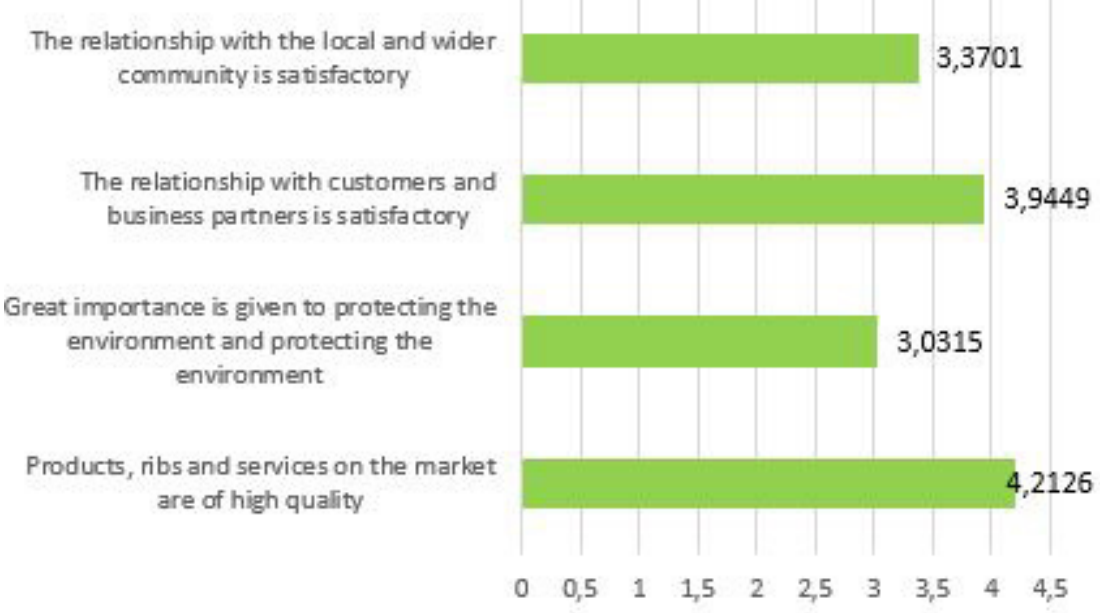

Source: author own study

Chart 3 shows the attitude of enterprises according to CSR provisions, which shows that the companies in the observed sample pay the highest attention to the quality of their products, goods and services, as well as to their relations with customers, which is visible by the average rating of about 4 of all observed companies in the sample . Somewhat less attention is paid to the attitude towards the local community, while the least attention is paid to environmental protection and environmental protection, an average score of three was obtained from the observed sample of enterprises.

Further testing revealed the realization of the obligation to prepare integrated financial statements as shown in Chart 4. The obtained data are devastating because as many as $41.73 \%$ of the companies in the observed sample are not aware of the preparation of integrated financial statements, while only $15.75 \%$ of the companies tested are integrated financial statements and it could be assumed that these companies take the CSR concept seriously. 
Chart 4. Knowledge and preparation of integrated financial statements

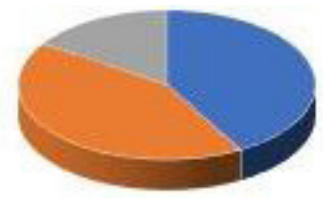

\section{- No, we are not aware of the obligation of such reporting \\ घyes, we are in the know, but we do not compose it \\ n Yes, we compile integrated business reports}

Source: author own study

For assessing the importance of interest groups in conducting CSR activities for the sample companies (SMEs), it can be seen that companies equally consider relevant legislation, employees, customers and suppliers with an average rating of approximately 4, while the global market is considered the least important (with an average score of 2.5) which was to be expected given that the sample is small and medium-sized enterprises with less interest in entering global markets.

Chart 5. Importance of interest groups for the enterprise in carrying out CSR activities (1-absolutely irrelevant, 2-irrelevant, 3- neither irrelevant nor important, 4-important, 5-absolutely important)

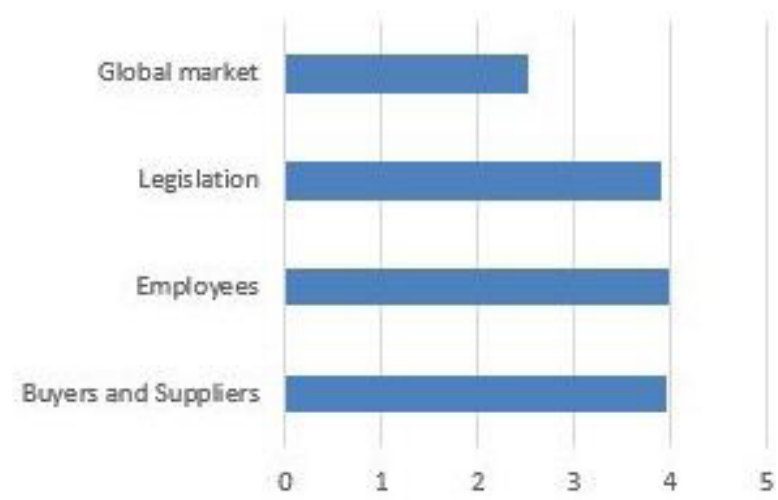

Source: author own study

When assessing the importance of business-related assumptions and elements of CSR conception in the observed sample of SMEs, it can be seen that the company is paying more attention to business effects, reducing operating costs, increasing sales and customer satisfaction (with an average score above 4), while elements of CSR conception such as environmental protection and investing in employee education are given less importance. 
Chart 6. Assessment of the importance of business-related assumptions and elements of CSR

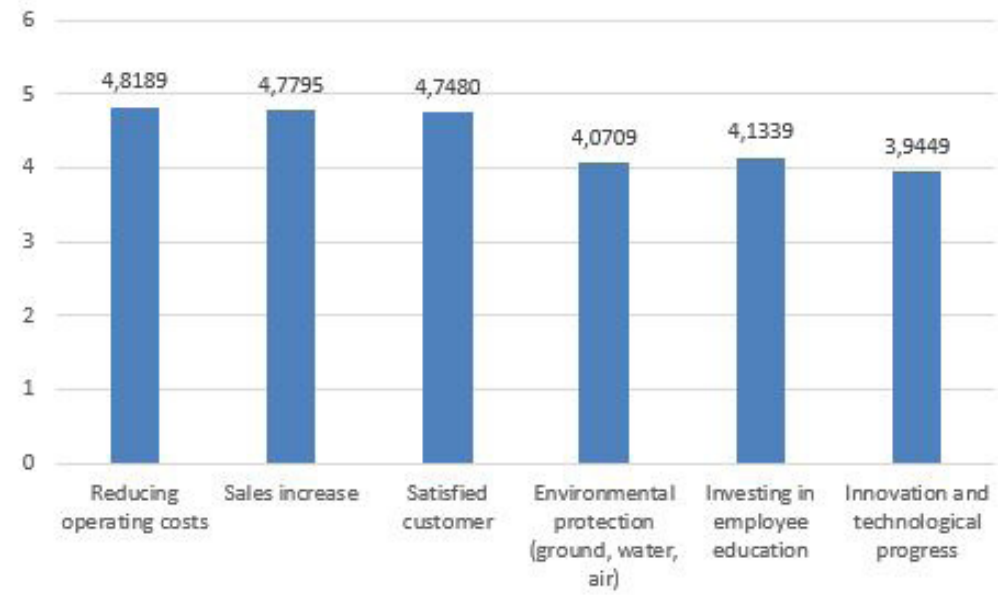

Source: author own study

The correlation coefficient tried to prove the correlation between performance indicators and stock prices on the capital market. In general, the correlation coefficient proves the relationship between two variables, which can be high or low, positive or negative. Very high positive correlation is indicated by variables that have a positive sign and a statistical significance of 0.01 (under the "*** Correlation is significant at the 0.01 level (2-tailed)."). The correlation coefficients between the analyzed indicators of CSR and ROS, ROA and ROE are presented in Table 1.

Table 1: Coefficients correlation ROS, ROA and ROE with the implementation of CSR strategies

Correlations

\begin{tabular}{|c|c|c|c|c|c|}
\hline & & CSR & ROS & ROA & ROE \\
\hline \multirow{3}{*}{ CSR } & Pearson Correlation & 1 & $256 * *$ &, $235 * *$ & $257 * *$ \\
\hline & Sig. (2-tailed) & &, 004 &, 008 &, 004 \\
\hline & $\mathrm{N}$ & 127 & 127 & 127 & 127 \\
\hline \multirow{3}{*}{ ROS } & Pearson Correlation &, $256 * *$ & 1 &, $683 * *$ & $400 * *$ \\
\hline & Sig. (2-tailed) &, 004 & &, 000 &, 000 \\
\hline & $\mathrm{N}$ & 127 & 127 & 127 & 127 \\
\hline \multirow{3}{*}{ ROA } & Pearson Correlation &, $235 * *$ &, $683 * *$ & 1 &, $266 * *$ \\
\hline & Sig. (2-tailed) &, 008 &, 000 & & ,002 \\
\hline & $\mathrm{N}$ & 127 & 127 & 127 & 127 \\
\hline \multirow{3}{*}{ ROE } & Pearson Correlation &, $257 * *$ &, $400 * *$ &, $266 * *$ & 1 \\
\hline & Sig. (2-tailed) & ,004 &, 000 &, 002 & \\
\hline & $\mathrm{N}$ & 127 & 127 & 127 & 127 \\
\hline
\end{tabular}

**. Correlation is significant at the 0.01 level (2-tailed).

Source: author own study 
The ROS, ROA and ROE indicators are moderately positively correlated with the CSR strategy in small and medium-sized enterprises in the Republic of Croatia, which shows us the significant correlation between the indicators (statistical significance $0.01)$.

Figure 1: Scatter diagrams ROS, ROA and ROE with the implementation of CSR strategies
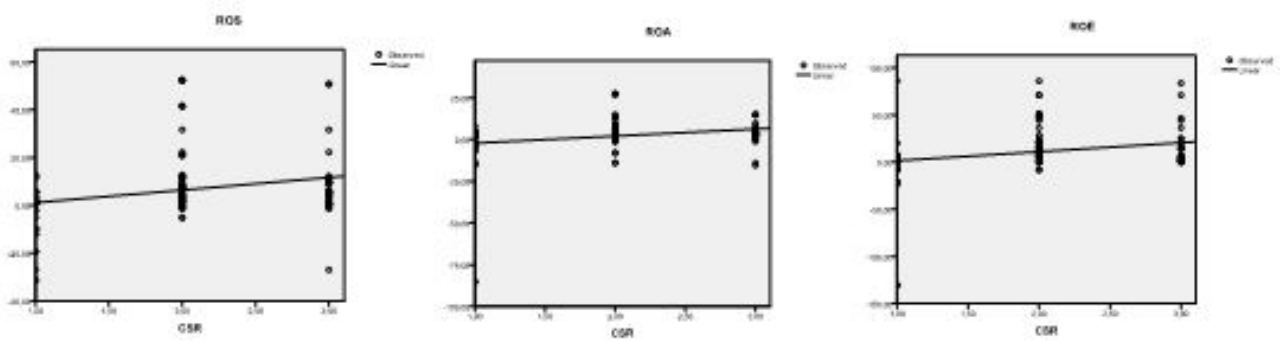

Source: author own study

Figure 1 shows the scatter diagrams for the above indicators of ROS, ROA and ROE with the application of CSR strategies in small and medium-sized enterprises of the Republic of Croatia, which show how, although small, correlation exists, and that the variables are positively correlated. The scatterplots show the results of the study, which show a partial correlation between the observed variables.

Based on the conducted research, Table 1 shows the correlation and regression coefficients of the analysis of the statistical significance of the correlation between the degree of application of CSR concept and Net profit margin, Return on total assets, Return on equity.

Table 2: Statistical representation of correlation and regression CSR and ROS, ROA, ROE

\begin{tabular}{|c|c|r|r|r|r|r|r|r|r|r|r|}
\hline \multirow{2}{*}{ Model } & \multirow{2}{*}{$\mathbf{R}$} & \multirow{2}{*}{$\begin{array}{c}\mathbf{R} \\
\text { Square }\end{array}$} & $\begin{array}{c}\text { Adjusted } \\
\text { R Square }\end{array}$ & $\begin{array}{c}\text { Std. Error } \\
\text { of the } \\
\text { Estimate }\end{array}$ & $\begin{array}{c}\text { Square } \\
\text { Change }\end{array}$ & $\begin{array}{c}\text { R } \\
\text { Change }\end{array}$ & df1 & df2 & $\begin{array}{c}\text { Sig. F } \\
\text { Change }\end{array}$ & $\begin{array}{c}\text { Dubin- } \\
\text { Watson }\end{array}$ \\
\hline 1 &, $256^{\mathrm{a}}$ &, 065 &, 058 & 14,67051 &, 065 & 8,746 & 1 & 125 &, 004 & 2,109 \\
\hline 2 &, $235^{\mathrm{a}}$ &, 055 &, 048 & 12,96136 &, 055 & 7,285 & 1 & 125 &, 008 & 2,219 \\
\hline 3 &, $257^{\mathrm{a}}$ &, 066 &, 058 & 26,53388 &, 066 & 8,828 & 1 & 125 &, 004 & 2,133 \\
\hline
\end{tabular}

a. Predictors: (Constant), CSR

b. Dependent Variable: ROS, ROA, ROE

Source: author own study

From the correlation coefficient $\mathrm{R}$ in Table 1. we can see that the correlation between the variables CSR and ROS exists (0.256), CSR and ROA exists (0.235) and CSR and REO exist (0.257) but in all observed cases it is extremely small. 
For all the observed variables ROS, ROA and ROE the coefficient of determination R2 is closer to zero than unity, so we cannot speak of a good linear relationship between the models. F ratio is higher than the theoretical value because the samples are not from the same economic activity, on the basis of the given significance level 0.05 and with the number of degrees of freedom (1.125) we conclude that the degree of application of the CSR concept is partially but not significantly related to financial efficiency ROS, ROA and REO. Durbin-Watson has a value of 2 indicating that there is no auto correlation of relation errors. The analysis of the obtained data should conclude that the hypothesis H1 was not confirmed.

The following data are presented in Charts 7 and 8 from the survey conducted on a sample of 127 Croatian small and medium-sized enterprises of the research company $\mathrm{H} 2=$ Small and medium-sized enterprises of the Republic of Croatia attach great importance to the implementation of the CSR strategy observed SMEs, came to the realization that as $47 \%$ of enterprises attach the most importance to humanitarian and charitable work, while $17 \%$ of enterprises lead environmental and environmental brokers, but the devastating fact is that $15 \%$ of enterprises from the observed sample do not applies no CSR measures, as can be seen in Chart 7. Furthermore, only $13 \%$ of enterprises continuously invest in education and development of their employees, while the concern for employee health and satisfaction is at the last place with $8 \%$.

Chart 7. Demonstration of the application of CSR measures

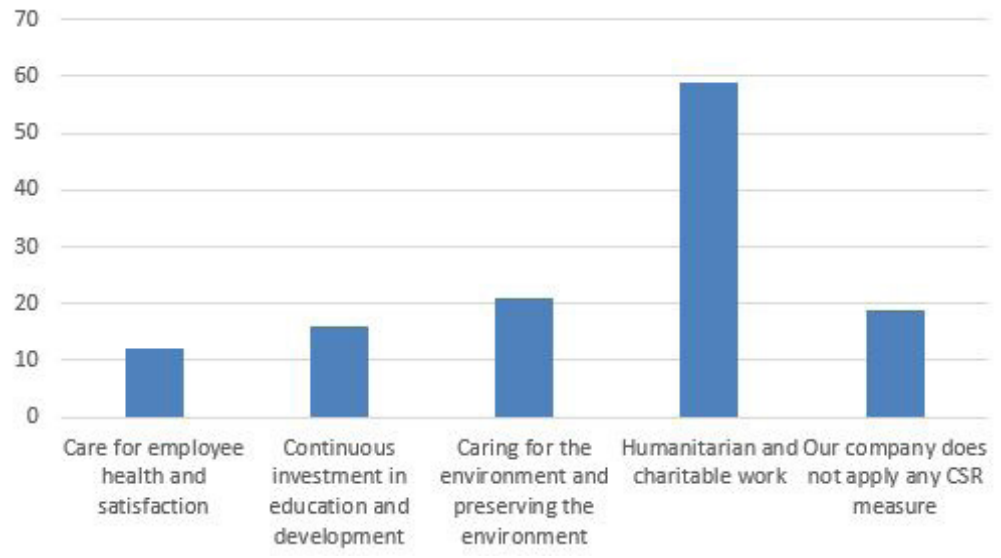

Source: author own study 
Chart 8. Corporate attitude towards CSR

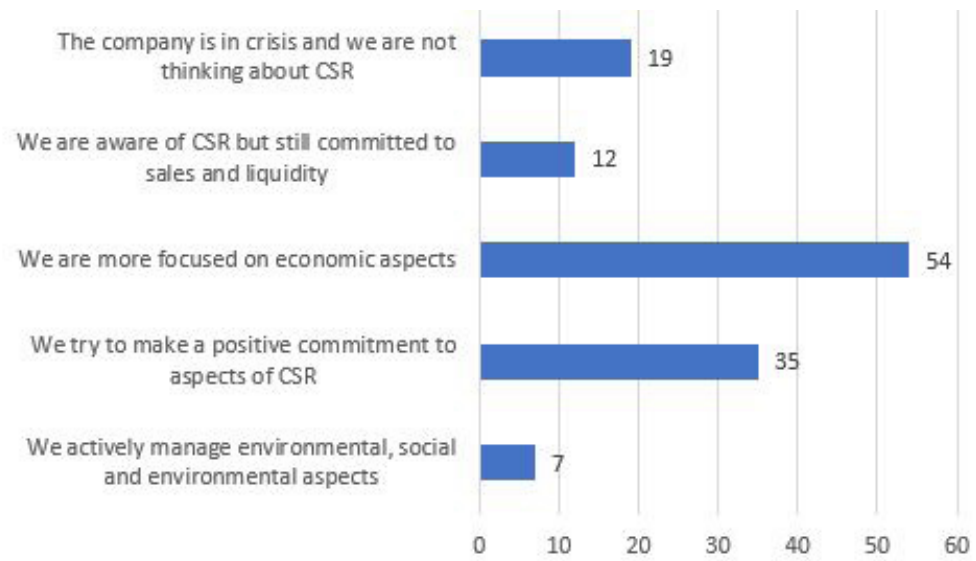

Source: author own study

The results of the survey presented in Chart 8 show that $42.52 \%$ of Croatian SMEs are mostly focused on economic aspects of their business, but it is also a devastating fact that only $5.51 \%$ of companies from the analyzed sample actively apply the concept CSR through all three aspects (economic, social and environmental). However, $27.56 \%$ of companies are committed to positively addressing CSR aspects, while $9.45 \%$ of companies are aware of the need to implement CSR but are still more committed to maintaining sales and liquidity levels. Enterprises with difficulties in business, those enterprises in crisis situation, $14.96 \%$ of them do not think about CSR at all. Based on the conducted research and the data obtained in Charts 7 and 8, it is concluded that SMEs in the Republic of Croatia do not attach sufficient importance to the implementation and implementation of CSR strategy and it is concluded that hypothesis $\mathrm{H} 2$ has not been confirmed.

In this study, two hypotheses were presented, which were presented in detail before and it can be seen that the hypotheses were not confirmed and therefore it can be concluded that there is no statistically significant correlation between the application of CSR concept in small and medium sized enterprises with the efficiency of business, which was measured by Net profit margin, Return on Total Assets and Return on Equity and that the SMEs of the Republic of Croatia do not attach much importance to the application of the CSR concept.

Regarding the limitations of the research, it should be noted that they still exist, primarily because the survey received only 127 valid surveys and since these are small and medium-sized enterprises with limited access to capital and financial resources necessary for business, they are not very interested in CSR strategy as well as research on the same. 


\section{CONCLUSION}

Corporate social responsibility is nowadays one of the main factors for successful business operations of large companies, especially those operating in the global market. Therefore, there is a growing focus on the focus on the application of the concept of CSR in SMEs, as CSR has become a global concern that needs to be addressed if it is to gain a competitive advantage in the market. Undoubtedly, there is an unquestionable competitive advantage for customers and consumers that companies achieve by applying the CSR concept. The results of this research show that small and medium-sized enterprises in the Republic of Croatia do not pay much attention to the application of the CSR concept, although they are largely focused on achieving high quality of products, goods and services and rank highly buyers and consumers as an interest group for conducting CSR activities. On the other hand, companies attach less importance to environmental protection than achieving customer satisfaction, increasing sales and reducing operating costs. Since the survey was conducted on a relatively small sample (valid surveys) of small and medium-sized enterprises of the Republic of Croatia, because of their size, have limited access to capital and financial resources, small enterprises find it much more difficult to maintain liquidity than large ones, hence their small orientation the application of the concept of CSR was expected. Most of the enterprises in the observed sample do not apply CSR strategy, but are primarily focused on economic aspects of business and this study obtained data on the statistical correlation between variables CSR and ROS exists (0.256), CSR and ROA exists (0.235), and CSR and REO exists (0.257) but in all observed cases it is extremely small, while visible partial linear relationship between the observed variables.

As the aim of each company is to remain well positioned in the market, as well as the presence of pressure from external stakeholders on buyers and consumers first, it is expected that SMEs will in the future apply the concept of CSR to retain a competitive position in the market. Therefore, it would be good to carry out similar research in the future in order to analyze the quality and quantity of possible improvements in the implementation of CSR strategy in SMEs. To analyze in the future whether there are any improvements in the implementation of the CSR strategy in order to analyze the contribution of the CSR in achieving better financial results, and also to make a comparative analysis with SMEs in the region as well as the position of Croatia in relation to the region. 


\section{LITERATURE}

1. CSR for SMEs, publicly available at http://www.csrhub.ie/csr-for-smes/ [access 15.december 2019]

2. Hopkins M., 2006. „What is Corporate Social Responsibility all about“, JohnWiley\&Sons, Ltd., Journal of Public Affairs, Volume 6, Issue 3-4, August - November, pp.299., publicly available at http://onlinelibrary.wiley.com/ doi/10.1002/pa.v6:3/4/issuetoc [access 05.december 2019]

3. Leadbeater, C. 1997. The Rise of the Social Entrepreneur, London: Demos

4. Maloni, M.J. and Brown, M.E. 2006. „Corporate social responsibility in the supply chain: an application in the food industry“. Journal of Business Ethics, 68:1, pp.35-52.

5. Spence, L.J., Schmidpeter, R. and Habisch, A. 2003. „Assessing social capital: small and medium-sized enterprises in Germany and the UK“. Journal of Business Ethics, 47:1, pp.17-29.

6. Tilley, F. 2000. „Small firm environmental ethics: how deep do they go?“ Business Ethics: A European Review, 9:1, pp.31-41.

7. Vallentin, S. and Morsing, M. 2008. „Social responsibility in Danish SMEs: mapping the territory“. In: CSR in SMEs: pp. 8-36. Copenhagen: Borsen Forlag

8. Vinšalek Stipić, V. 2017. „Društveno odgovorno poslovanje kao preduvjet stvaranja vrijednsoti poduzeća“. Zbornik radova 18 . Međunarodna znanstvena i stručbna konferencija „Računovodstvo i menadžemnt“, Svezak I - znanstveni radovi. Opatija. pp. 189-202.

9. McWilliams, A. and Siegel, D. 2000. „Corporate social responsibility and financial performanse: Correlation or misspecification?“. Starategic management Journal, Volume 2, No. 5, pp. 603-609.

10. World bank. 2005. Working papers: Opportunities and Optios for Governments to Promote Corporate Social Responsibility in Europe and Central Asia. Washington, publicly available at http://siteresources.worldbank.org/EXTDEVCOMMENG/Resources/csrbooklet31705.pdf $\square$ access 02.december 2019 $\square$ 
Valentina Vinšalek Stipić

\section{DRUŠTVENO ODGOVORNO POSLOVANJE MALIH I SREDNJIH PODUZEĆA U REPUBLICI HRVATSKOJ}

\section{SAŽETAK}

Gledano s dugoročnog aspekta moderni kapitalizam ne zahtjeva od poduzeća samo ostvarivanje što većeg profita nego se sve više pozornosti posvećuje socijalnim i ekološkim problemima poslovanja. Prvenstveno se to odnosi na zadovoljavanje socijalnih i ekoloških potreba šire društvene zajednice. Klimatske promjene koje utječu na izumiranje bioloških vrste što, za posljedicu ima velikog utjecaja na život čovjeka, te globalna ekonomska kriza koja od korporacija sve više zahtijeva brigu o globalnom utjecaju na okoliš i bio održivost čovjeka, zahtijevaju jačanje korporativne odgovornosti sa sve većom pozornošću na socijalni i ekološki problem. Glavni cilj ovog rada je ispitati zastupljenost strategije društveno odgovornog poslovanja u malim i srednjim poduzećima Republike Hrvatske, promatrajući kroz ekonomsku, socijalnu i ekološku dimenziju. Napravljena je analiza primjene, odnosno postojeće razine društveno odgovornog poslovanja, kao i usporedba razina implementacije društvene i ekološke dimenzije u promatranim malim i srednjim poduzećima. Empirijskim istraživanje u ovom radu može se zaključiti kako su mala i srednja poduzeća iz uzorka orijentirana na operativni i financijski aspekt poslovanja, dok se ujedno donose poslovne strategije kroz sve tri dimenzije društveno odgovornog poslovanja.

Ključne riječi: Društveno odgovorno poslovanje, mala i srednja poduzeća

JEL: $L 26, Q 56, G 32$ 